\title{
Laminin Coating Promotes Calcium Phosphate Precipitation on Titanium Discs in vitro
}

\author{
Kostas Bougas $^{1,4}$, Victoria Franke Stenport ${ }^{2,4}$, Pentti Tengvall ${ }^{4}$, Fredrik Currie ${ }^{3}$, Ann Wennerberg ${ }^{1,4}$ \\ ${ }^{1}$ Department of Prosthodontics, Faculty of Odontology, Malmö University, Malmö, Sweden. \\ ${ }^{2}$ Department of Prosthodontics, Faculty of Odontology, Sahlgrenska Academy, Göteborg University, Göteborg, Sweden. \\ ${ }^{3}$ Promimic AB, Göteborg, Sweden. \\ ${ }^{4}$ Department of Biomaterials, Institute of Clinical Sciences, Sahlgrenska Academy, Göteborg University, Göteborg, Sweden.
}

\author{
Corresponding Author: \\ Kostas Bougas \\ Department of Prosthodontics, Faculty of Odontology, Malmö University \\ 20506 Malmö \\ Sweden \\ Phone: +46406658520 \\ Fax: +46406658503 \\ E-mail: kostas.bougas@mah.se
}

\begin{abstract}
Objectives: The objective of this study was to investigate the effect of a laminin coating on calcium phosphate precipitation on three potentially bioactive titanium surfaces in simulated body fluid.

Material and Methods: Blasted titanium discs were prepared by alkali and heat treatment (AH), anodic oxidation (AO) or hydroxyapatite coating (HA) and subsequently coated with laminin. A laminin coated blasted surface (B) served as a positive control while a blasted non coated (B-) served as a negative control. Surface morphology was examined by Scanning Electron Microscopy (SEM). The analysis of the precipitated calcium and phosphorous was performed by Energy Dispersive X-ray Spectroscopy (EDX).

Results: The thickness of the laminin coating was estimated at $26 \AA$ by ellipsometry. Interferometry revealed that the coating process did not affect any of the tested topographical parameters on $\mu \mathrm{m}$ level when comparing B to B-. After 2 weeks of incubation in SBF, the alkali-heat treated discs displayed the highest calcium phosphate deposition and the B group showed higher levels of calcium phosphate than the B- group.

Conclusions: Our results suggest that laminin may have the potential to be used as a coating agent in order to enhance the osseoinductive performance of biomaterial surfaces, with the protein molecules possibly functioning as nucleation centres for apatite formation. Nevertheless, in vivo studies are required in order to clarify the longevity of the coating and its performance in the complex biological environment.
\end{abstract}

Keywords: laminin; titanium; biomaterials; calcium phosphates; dental implants; osseointegration.

Accepted for publication: 16 September 2011

To cite this article:

Bougas K, Stenport VF, Tengvall P, Currie F, Wennerberg A. Laminin Coating Promotes Calcium Phosphate Precipitation on Titanium Discs in vitro.

J Oral Maxillofac Res 2011 (Oct-Dec);2(4):e5

URL: http://www.ejomr.org/JOMR/archives/2011/4/e5/v2n4e5ht.pdf

doi: $10.5037 /$ jomr.2011.2405 


\section{INTRODUCTION}

Bone anchored titanium implants are widely used in the rehabilitation of edentulism. In order to enhance bone growth around implants, various chemical modifications of titanium surfaces have been proposed. Some techniques are alkali-heat treatment (AH) [1], anodization [2], coatings of calcium phosphates in sol-gels [3] and immobilization of organic bio-molecules on the surface [4]. The simulated body fluid (SBF) model has been extensively utilized for in vitro evaluation of various materials and surface modification methods [5-7]. The SBF is defined as a solution with ion concentrations approximately equal to those of human blood plasma [8-10]. The nucleating capacity of a biomaterial can be observed by immersing it in SBF [11]. It has been suggested that the nucleation of calcium/phosphates from SBF, mimics the initial mineralization of bone on the implant surface. The correlation between apatite formation in SBF models and bone bioactivity in vivo has been described in a review on the usefulness of SBF in predicting in vivo bone bioactivity [12]. However, compared to the SBF model, the in vivo process is much more complex and proteins, enzymes and biological factors play a crucial role in this process [13].

Laminin is an organic biomolecule previously utilized with success for improving the attachment of mesenchymal stem cells on $\mathrm{TiO}_{2}$ nanotubes [14] and for enhancing the epithelial cell attachment on Ti-6Al-4V implants in vitro $[\underline{15}, \underline{16}]$. Laminins are heterotrimeric glycoprotein molecules that bind to a protein family known as integrins, especially $\beta 1$ and $\beta 2$ integrins [17]. Integrins are integral membrane glycoproteins which mediate cell-to-cell and cell-tomatrix interactions. Integrins are known to mediate cell adhesion to extracellular matrix and to facilitate the cell communication [18]. One of their key functions is to participate in the assembly of the cytoskeleton and thereby resulting in cell migration, adhesion of epithelial cells and hemidesmosome formation by their cytoplasmic domains [17]. In vitro studies indicate that laminin-1 selectively recruits osteoprogenitors through an integrin $\beta 1$-dependent cell attachment effect $[19, \underline{20}]$ and possesses the ability to stimulate osteoblasts to produce alkaline phosphatase and deposit mineral [21]. Our hypothesis is that by coating titanium surfaces with laminin-1 enhanced precipitation of $\mathrm{CaP}$ in an SBF model may be achieved.

The aim of the present study was to investigate the effects of laminin coating on titanium surfaces modified by three methods claimed to provide bioactivity in terms of $\mathrm{Ca} / \mathrm{P}$ precipitation, surface morphology and surface chemistry in simulated body fluid.

\section{MATERIAL AND METHODS}

\section{Surface preparations}

Ninety discs $($ diameter $=8 \mathrm{~mm}$, thickness $=1 \mathrm{~mm})$ of titanium grade 4 were included in the study. The samples were blasted with $\mathrm{Al}_{2} \mathrm{O}_{3}$ powder with an average particle size of $120 \mu \mathrm{m}$ with a force of $3.5 \mathrm{~kg}$ and from a distance of $15 \mathrm{~mm}$ and subsequently ultrasonically cleaned in diluted Extran MA01 and absolute ethanol and dried at $60{ }^{\circ} \mathrm{C}$ for $24 \mathrm{~h}$. The specimens were then divided into five equally sized groups $(n=18)$. One group of blasted discs was coated with laminin and served as a positive control (B), while a non laminin-coated group of blasted specimens served as a negative control (B-). The other three groups were treated as follow and were ultimately coated with laminin.

\section{Alkali and heat treatment (AH)}

Alkali and heat treatment was performed as described in the literature $[\underline{10}, \underline{22}, \underline{23}]$. In brief, the discs were soaked in $5 \mathrm{M}$ aqueous $\mathrm{NaOH}$ for $24 \mathrm{~h}$ at $60^{\circ} \mathrm{C}$, rinsed with distilled water and dried at $40^{\circ} \mathrm{C}$ for $24 \mathrm{~h}$. Subsequently, the discs were heated until reaching $600^{\circ} \mathrm{C}$ by increasing the temperature by $5{ }^{\circ} \mathrm{C} / \mathrm{min}$ in an electrical furnace (Bitatherm, Bita Laboratory Furnaces, Israel) and were kept at $600{ }^{\circ} \mathrm{C}$ for $2 \mathrm{~h}$. At the end of the process, the discs were left in the furnace until they cooled down to room temperature.

\section{Anodic oxidation (AO)}

The samples were prepared in a mixed electrolyte containing calcium ions by the Micro Arc Oxidation (MAO) method in a galvanostatic mode as described in the literature [24]. More specifically, the electrochemical cell was composed of platinum plates as cathodes with a titanium anode at the centre. A computer interfaced with a DC power supply was used to record currents and voltages at milliseconds intervals. The content of ripple was controlled to less than $0.1 \%$ [25] . Surface analysis of the oxidized surfaces demonstrated the following properties: a calcium content of 11 atomic percent in the newly formed oxide of $1.2 \mu \mathrm{m}$ thickness, $24 \%$ porosity and mixed anatase and rutile crystal structure $[\underline{26}, \underline{27}]$.

\section{Hydroxyapatite coating ( $\mathrm{HA})$}

A thin hydroxyapatite layer $(<50 \mathrm{~nm})$ was obtained by dipping the titanium discs (Ti-discs) into a solution containing surfactants, water, organic solvent and crystalline hydroxyapatite particles with a $\mathrm{Ca} / \mathrm{P}$ ratio of 1.67. The diameter of the hydroxyapatite particles 
was approximately $10 \mathrm{~nm}$. After the dipping procedure, the discs were let to dry in open air for $30 \mathrm{~min}$, allowing the organic solvent to evaporate. To remove all dispersing agents, the discs were subjected to heat treatment at $550^{\circ} \mathrm{C}$ for $5 \mathrm{~min}$ [료]

\section{Laminin coating and quantification}

\section{Laminin coating}

Laminin (Sigma-Aldrich, L2020, Stockholm, Sweden) was diluted to a concentration of $100 \mu \mathrm{g} / \mathrm{ml}$ in PBS containing $0.15 \mathrm{M} \mathrm{NaCl}$, at $\mathrm{pH} 7.4$ at room temperature. The titanium discs belonging to groups $\mathrm{B}, \mathrm{AH}, \mathrm{AO}$ and HA were subsequently incubated for $1 \mathrm{~h}$ at room temperature in 48 well plates (Nunclon Surface, Nunc, Roskilde, Denmark) containing $250 \mu \mathrm{l}$ per well of the laminin solution. The discs were then rinsed with Milli-Q water and blown dry in order to avoid deposition of salts and remove non-adsorbed proteins.

\section{Optically smooth titanium surface preparation}

For quantification of adsorbed laminin layer optically smooth titanium surfaces were prepared as described by Linderbäck et al. [29] ]. Cleaned $\mathrm{SiO}_{2}$ surfaces were placed in an evaporation chamber with a final pressure below $1 \times 10^{-8}$ Torr. Approximately $200 \mathrm{~nm}$ of titanium was physical vapour deposited (PVD), and thereafter spontaneously oxidized at room conditions. The static water contact angle of optically smooth titanium was $\Theta<10^{\circ}$ at room conditions and $>50^{\circ}$ after heating to $300-500{ }^{\circ} \mathrm{C}$ at room conditions for $30 \mathrm{~min}$. The effect of UVO-treatment (Ultra Violet Ozone) was investigated on a set of surfaces illuminated for up to 96 $h$ in a UVO preparation chamber (Jelight Company Inc., Irvine-USA). The wavelengths of the emitted light were $253.7 \mathrm{~nm}(100 \%)$ and $184.9 \mathrm{~nm}(19 \%)$, respectively. The samples were placed within $2 \mathrm{~cm}$ from the lamp (Novakemi AB, Handen-Sweden), and the UVOchamber temperature was below $100{ }^{\circ} \mathrm{C}$. Changes in surface hydrophilicity prior and subsequent to UVOillumination or annealing was characterized using an OCA 15 plus contact angle microscope (CAM) used in sessile drop mode (Dataphysics Instruments $\mathrm{GmBH}$, Filderstadt, Germany).

\section{Ellipsometry}

The amount adsorbed laminin was calculated on the optically smooth titanium surfaces. The surface treated discs were not possible to analyze, since these surfaces did not reflect the laser beam in a measurable manner. Optically smooth titanium surfaces were fixed in the ellipsometric quvette filled with PBS at room temperature. The ellipsometry angles $\Delta_{0}$ and $\Psi_{0}$ were measured with a Rudolph Research
AutoEL III ellipsometer operating in a wavelength of $632.8 \mathrm{~nm}$ at a $70^{\circ}$ angle of incidence. Thereafter, the quvette was emptied and filled with laminin solution and new angles $\Delta$ and $\Psi$ calculated. The protein layer thickness was iterated from the ellipsometer angle changes under the assumption that the protein refractive index was $\mathrm{n}=1.465$. The McCrackin algorithm was used for the calculations [푸] .

\section{SBF immersion}

The revised SBF (r-SBF) used in this study was prepared according to the literature [31]. In brief, $5.403 \mathrm{~g} \mathrm{NaCl}$ (Merck, Darmstadt, Germany), $0.740 \mathrm{~g}$ $\mathrm{NaHCO}_{3}$ (Merck, Darmstadt, Germany), $2.046 \mathrm{~g} \mathrm{Na}_{2} \mathrm{CO}_{3}$ (Merck, Darmstadt, Germany), $0.225 \mathrm{~g} \mathrm{KCl}$ (Merck, Darmstadt, Germany), $0.230 \mathrm{~g} \mathrm{~K}_{2} \mathrm{HPO}_{4} \cdot 3 \mathrm{H}_{2} \mathrm{O}$ (Merck, Darmstadt, Germany), $0.311 \mathrm{~g} \mathrm{MgCl}_{2} \cdot 6 \mathrm{H}_{2} \mathrm{O}$ (Merck, Darmstadt, Germany), 11.928 g 2-(4-[2-hydroxyethyl]1-piperazinyl) ethanesulfonic acid (HEPES) (Reach Organics Inc., Cleveland, Ohio, USA), $0.293 \mathrm{~g} \mathrm{CaCl}_{2}$ (KEBO Lab AB, Spånga, Sweden) and $0.072 \mathrm{~g} \mathrm{Na}_{2} \mathrm{SO}_{4}$ (Merck, Darmstadt, Germany) were dissolved in 1000 $\mathrm{ml}$ distilled water. HEPES was dissolved in $100 \mathrm{ml}$ distilled water before being added to the solution and the final $\mathrm{pH}$ was adjusted to 7.4 at $37^{\circ} \mathrm{C}$.

The discs were immersed in $25 \mathrm{ml}$ r-SBF in separate sealed polystyrene vials at $37{ }^{\circ} \mathrm{C}$. After immersion for $1 \mathrm{~h}, 1$ day, 3 days, 1 week and 2 weeks, the r-SBF immersion was interrupted and the specimens rinsed with distilled water in order to remove any loosely attached calcium phosphate. Thereafter, the specimens were left to dry at room temperature and ultimately sealed in dry vials. Three samples of each type of surface were not immersed in r-SBF (0 hours).

\section{Topographic characterization}

The specimens were topographically characterized after immersion in r-SBF with an interferometer MicroXam (Phase-Shift, Tucson, Arizona, USA) operating in a wave length of $\lambda=550 \mathrm{~nm}$.

A Gaussian filter with size $50 \times 50 \mu \mathrm{m}^{2}$ was applied to separate roughness from form and waviness. Thereafter, the surface roughness was calculated by using the following topographical parameters defined as essential for describing the topography of biomaterial surfaces [32]:

$\mathrm{S}_{\mathrm{a}}=$ Arithmetic mean height deviation from a mean plane $(\mu \mathrm{m})$.

$\mathrm{S}_{\mathrm{ds}}=$ Density of summits, i.e. the number of summits of a unit sampling area $\left(\mu \mathrm{m}^{-2}\right)$.

$\mathrm{S}_{\mathrm{dr}}=$ Developed interfacial area ratio, i.e. the ratio of the increment of the interfacial area of a surface over 
the sampling area $(\%)$.

Calculations of group means and standard errors for each surface preparation and time point were performed.

\section{Scanning electron microscopy/energy dispersive $\mathrm{X}$-ray analysis (SEM/EDX)}

For the SEM analysis, a LEO Ultra 55 FEG SEM equipped with an Oxford Inca EDX system, operating at 8 and $10 \mathrm{kV}$ was used. The samples were examined without surface sputtering. Micrographs were recorded at different magnifications to investigate both the surface coverage and the morphology of the crystals. EDX analysis at a magnification of 150 times was performed to describe the atomic composition. Two samples from each surface composition. Three titanium discs for each preparation and incubation time were analyzed and a mean value calculated.

\section{Statistical analysis}

The normal distribution of the variables was confirmed by Kolmogorov - Smirnov test. Statistical analysis was performed with Statistical Package for the Social Sciences for Windows, version 18 (SPSS ${ }^{\circledR}$, Chicago, Illinois, USA) using one-way ANOVA (Analysis of Variance). The multiple paired comparisons were performed by Bonferroni Post-Hoc test. The statistical significance level was defined at 0.05 .

\section{RESULTS}

\section{Topographical analysis}

As demonstrated by Table 1, the laminin coating elicited no difference on the examined topographic parameters $\mathrm{S}_{\mathrm{a}}, \mathrm{S}_{\mathrm{ds}}$ and $\mathrm{S}_{\mathrm{dr}}$ when comparing group $\mathrm{B}$ and group $\mathrm{B}$ $(\mathrm{P}>0.05)$. Treatment of the titanium discs with alkali and heat resulted in the lowest $\mathrm{S}_{\mathrm{a}}$ and the highest density of summits $(\mathrm{P}<0.05)$ among the tested surface modifications. As a total, the $\mathrm{AH}$ - group possessed the highest developed interfacial area ratio resulting in larger total surface.

\section{Ellipsometry}

The thickness of the adsorbed protein was estimated to $26 \AA$, approximating $180 \mathrm{ng} / \mathrm{cm}^{2}$ [이] . The layer approximates two monolayers in thickness.

\section{SEM/EDX}

SEM-images were acquired with a $\times 5000$ magnification
Table 1. $\mathrm{S}_{\mathrm{a}}, \mathrm{S}_{\mathrm{ds}}$ and $\mathrm{S}_{\mathrm{dr}}$ for the five different surface groups. Mean values and standard errors are presented

\begin{tabular}{cccc}
\hline Surface & $\mathbf{S}_{\mathrm{a}}(\boldsymbol{\mu m})$ & $\mathbf{S}_{\mathrm{ds}}\left(\mu \mathbf{m}^{-2}\right)$ & $\mathbf{S}_{\mathrm{dr}}(\%)$ \\
\hline B- & $1.36 \pm 0.05$ & $153873.2 \pm 2585.8$ & $60.99 \pm 2.33$ \\
B & $1.30 \pm 0.07$ & $157884.7 \pm 6021.2$ & $60.13 \pm 5.85$ \\
AH & $1.24 \pm 0.09^{\mathrm{a}}$ & $234634.8 \pm 8454.7^{\mathrm{a}}$ & $84.61 \pm 2.32^{\mathrm{a}}$ \\
AO & $1.38 \pm 0.05$ & $171155.8 \pm 5768.1$ & $73.84 \pm 3.14$ \\
HA & $1.33 \pm 0.09$ & $168952.5 \pm 3574.2$ & $66.00 \pm 6.07$ \\
\hline
\end{tabular}

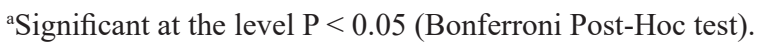

$\mathrm{B}-=$ uncoated blasted titanium; $\mathrm{B}=$ blasted and laminin coated; $\mathrm{AH}=$ alkali heat treated and laminin coated; $\mathrm{AO}=$ anodic oxidized and laminin coated; HA = hydroxyapatite and laminin coated.

prior to and after 2 weeks of incubation in r-SBF. The images prior to incubation demonstrated no differences in surface morphology when comparing the uncoated (Figure 1a) to the coated control blasted surface (Figure 1b). On the contrary, the alkali and heat treated titanium surfaces (Figure 1c) demonstrated a smooth surface, covered with microscopic spike-like structures and the anodic oxidated ones possesed a porous appearance (Figure 1d). However, no differences were detected in surface morphology when comparing the nano-sized hydroxyapatite coated surface (Figure 1e) to the controls (Figures 1a and 1b). All three surfaces displayed a sharp-edged appearance, which probably depended on the blasting procedure, and included some $\mathrm{Al}_{2} \mathrm{O}_{3}$ crystals. Nano-sized hydroxyapatite crystals could not be observed at this magnification. In general, no laminin molecules were observed at this magnification probably depending on the fact that the magnification was not high enough to reveal nano-sized features.

After 2 weeks of incubation in SBF, the surfaces B, AH and $\mathrm{AO}$ were fully covered with a homogenous calcium phosphate layer (Figures 2b, 2c and 2d). On the contrary, the HA surface (Figure 2e) and the B- surface (Figure 2a) appeared to be only partially covered by crystals.

\section{EDX}

\section{Calcium phosphate (CaP)}

The total amount of calcium phosphate on surfaces of titanium discs was assessed with EDX by measuring and adding the relative elemental amount of calcium $(\mathrm{Ca})$ and phosphorous $(\mathrm{P})$ present on the surface. $\mathrm{AH}$ surfaces showed the highest $\mathrm{Ca}$ and $\mathrm{P}$ content after 72 h, 1 week and 2 weeks. After 2 weeks no significant differences were detected among the test surfaces $\mathrm{AO}$, $\mathrm{HA}$ and the positive control B. At the same time, the negative control $\mathrm{B}$ - demonstrated the lowest $\mathrm{Ca}$ and $\mathrm{P}$ precipitation (Figure 3). 


\section{Calcium/Phosphorous ratio (Ca/P ratio)}

The proposed bioactive surfaces, i.e. AH, AO and HA treated samples, demonstrated a higher $\mathrm{Ca} / \mathrm{P}$ ratio than both blasted control samples (B and B-) during the first 24 hours. Noteworthy, calcium and phosphate signals were detected at an earlier time point on bioactive surfaces compared to blasted surfaces, depending on the bioactive modification process. The high early Ca content on the $\mathrm{AH}$ surface contributed to a high $\mathrm{Ca} / \mathrm{P}$ ratio. After 2 weeks of SBF immersion, all the surface groups presented a $\mathrm{Ca} / \mathrm{P}$ ratio around 1.67 , corresponding to hydroxyapatite crystalline formation (Figure 4). Interestingly, the high $\mathrm{Ca} / \mathrm{P}$ ratio of $\mathrm{AH}$ and $\mathrm{AO}$ surfaces at early time points decreases with increasing SBF incubation time.

\section{DISCUSSION}

Protein coatings have previously been used as a method to stimulate bone formation around implants in different experimental models with promising results [33-36]. Although there is a general agreement that a proper protein coating is promising in terms of enhanced osseointegration, there is still little known regarding the involved mechanisms. The main objective of this study was to study the etiology of the phenomenon in a controlled in vitro milieu as the SBF model.

The results demonstrate that all laminin coated surfaces induced a higher final $\mathrm{CaP}$ deposition as compared to uncoated blasted titanium after 2 weeks. The fact that all the "bioactively" modified surfaces, i.e. AH, AO, HA, demonstrate a higher $\mathrm{CaP}$ formation is in agreement with the findings of Arvidsson et al. [37]. The present study demonstrates that a thin laminin coating on a blasted titanium surface results to enhanced $\mathrm{CaP}$ precipitation as compared to a surface without laminin (B-) and
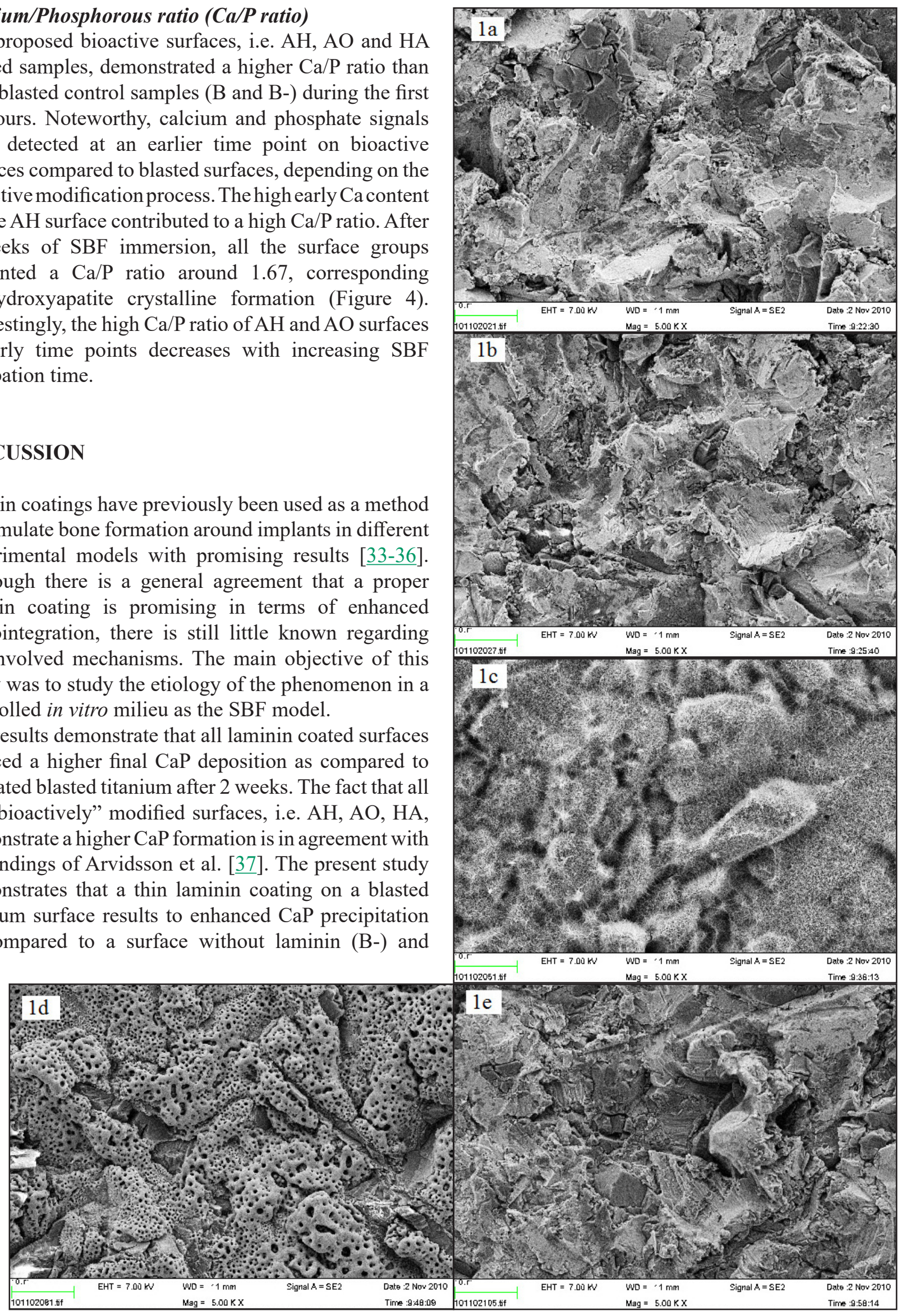

Figure 1. SEM images of titanium discs prior to incubation in SBF $(\times 5000)$ : (a) B- = uncoated blasted; (b) B = blasted and laminin coated; (c) $\mathrm{AH}=$ alkali heat treated and laminin coated; (d) $\mathrm{AO}=$ anodic oxidized and laminin coated; (e) $\mathrm{HA}=$ hydroxyapatite and laminin coated. The bar presents $10 \mu \mathrm{m}$. 

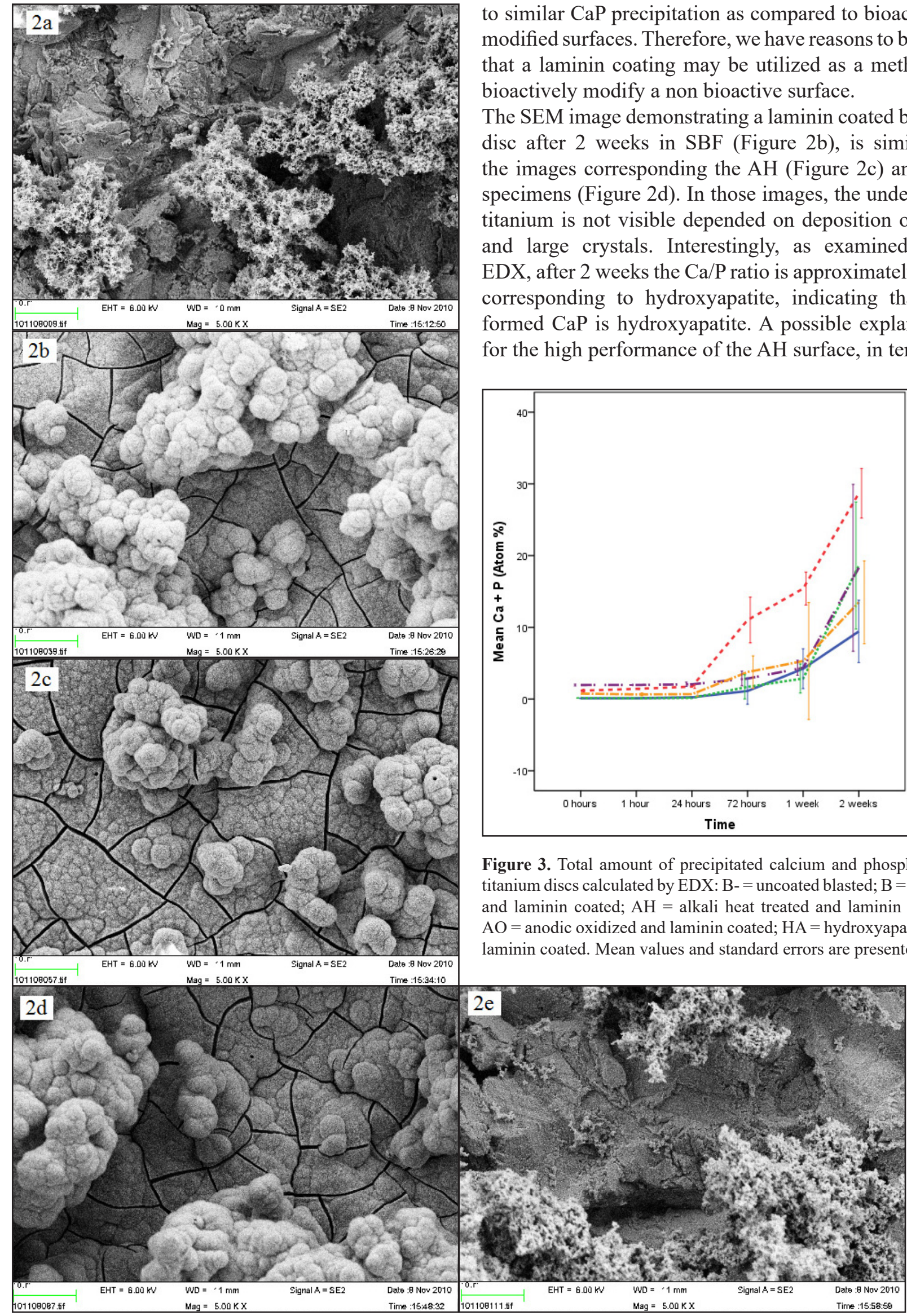

Figure 2. SEM image of a titanium discs after incubation in SBF for 2 weeks $(\times 5000)$ : (a) B- $=$ uncoated blasted; (b) $\mathrm{B}=$ blasted and laminin coated; (c) $\mathrm{AH}=$ alkali heat treated and laminin coated; (d) $\mathrm{AO}=$ anodic oxidized and laminin coated; (e) $\mathrm{HA}=$ hydroxyapatite and laminin coated. The bar presents $10 \mu \mathrm{m}$. to similar CaP precipitation as compared to bioactively modified surfaces. Therefore, we have reasons to believe that a laminin coating may be utilized as a method to bioactively modify a non bioactive surface.

The SEM image demonstrating a laminin coated blasted disc after 2 weeks in SBF (Figure 2b), is similar to the images corresponding the $\mathrm{AH}$ (Figure $2 \mathrm{c}$ ) and $\mathrm{AO}$ specimens (Figure 2d). In those images, the underlying titanium is not visible depended on deposition of $\mathrm{CaP}$ and large crystals. Interestingly, as examined with $\mathrm{EDX}$, after 2 weeks the $\mathrm{Ca} / \mathrm{P}$ ratio is approximately 1.67 corresponding to hydroxyapatite, indicating that the formed $\mathrm{CaP}$ is hydroxyapatite. A possible explanation for the high performance of the AH surface, in terms of

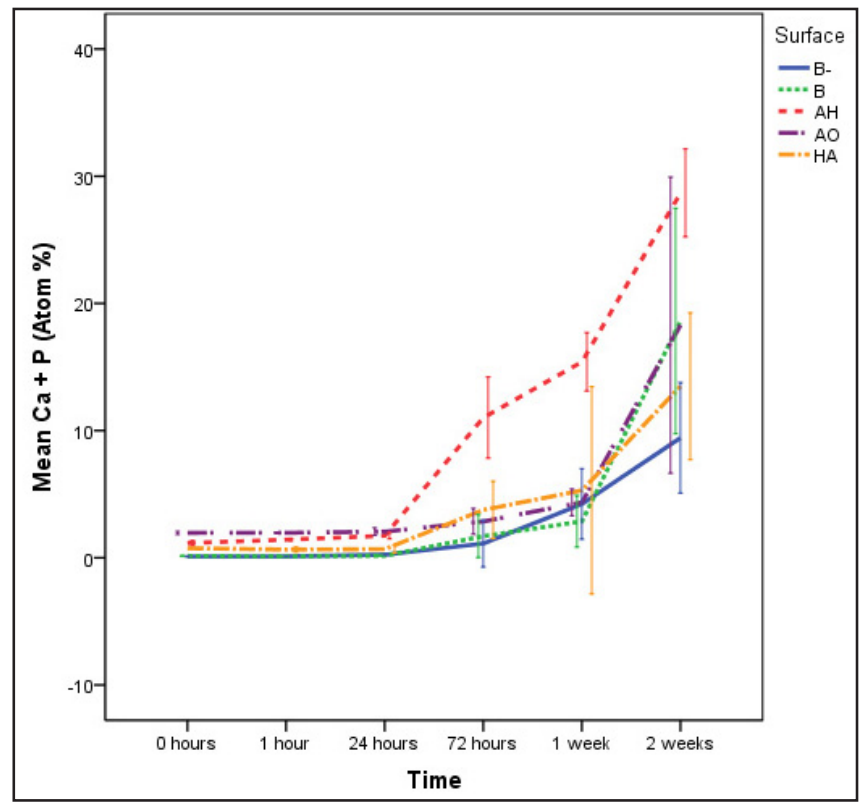

Figure 3. Total amount of precipitated calcium and phosphate on titanium discs calculated by EDX: B- = uncoated blasted; $\mathrm{B}=$ blasted and laminin coated; $\mathrm{AH}=$ alkali heat treated and laminin coated; $\mathrm{AO}=$ anodic oxidized and laminin coated $\mathrm{HA}=$ hydroxyapatite and laminin coated. Mean values and standard errors are presented. 


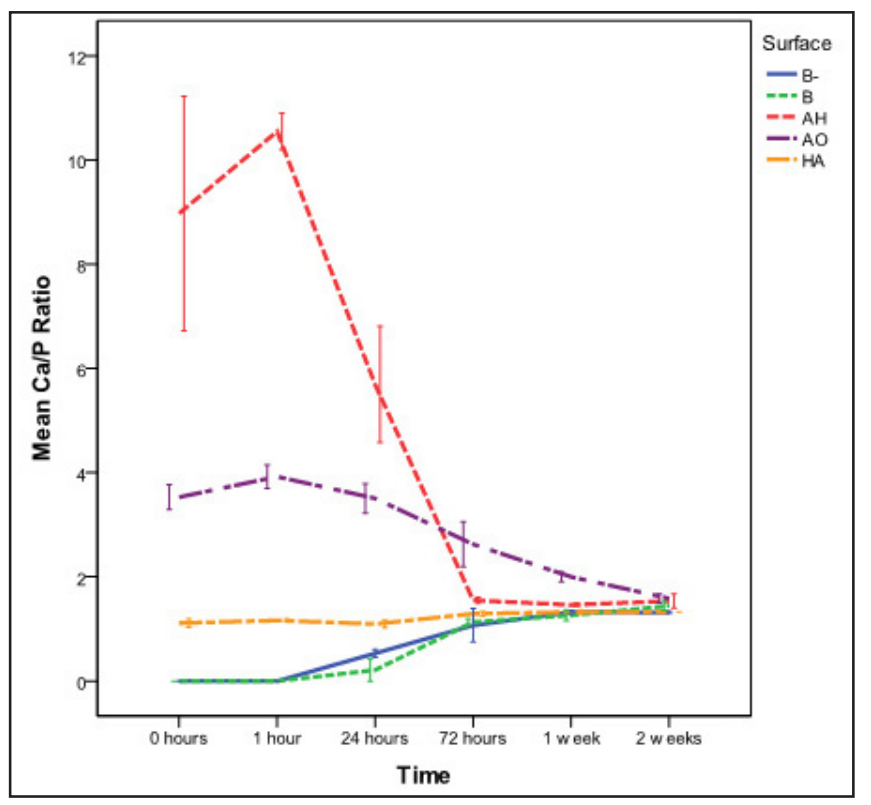

Figure 4. Calcium/phosphorous ratio on titanium discs calculated by EDX: B- = uncoated blasted titanium; $\mathrm{B}=$ blasted and laminin coated; $\mathrm{AH}=$ alkali heat treated and laminin coated; $\mathrm{AO}=$ anodic oxidized and laminin coated; HA = hydroxyapatite and laminin coated. Mean values and standard errors are presented.

$\mathrm{CaP}$ precipitation, may be the fact that the developed interfacial area ratio $S_{\mathrm{dr}}$ according to Table 1 is the highest among the tested surfaces, thereby providing a larger interface area with the SBF. This observation demonstrates that it is imperative to take into account at least one hybrid factor when characterizing surface topography, since considering solely $\mathrm{S}_{\mathrm{a}}$ may lead to false conclusions.

The results of a previous study from our group [38] suggest that a possible mechanism for laminin promoting $\mathrm{CaP}$ precipitation in vitro, may be its function as a nucleation centre. According to a morphological study examining the same laminin molecule that we utilized in the present study, laminin tends to assume a globular form when used for surface coating [39]. Some of the domains exposed on this protein conformation may act as nucleation centres for calcium ions thereby increasing the local calcium concentration, leading to enhanced nucleation ratio. In a recent study on osteoblasts the effect of elevated extracellular calcium concentration was proposed to stimulate osteoblasts through the receptor activator of NF- $\kappa B$ ligand [40]. Hence, it may be possible that the enhanced calcium and phosphate precipitation triggers osteoblast differentiation around a laminin coated implant also when applied in vivo. There is some indication that enhanced $\mathrm{CaP}$ precipitation may be relatively specific for laminin since coating with bovine serum albumin instead reduced $\mathrm{CaP}$ precipitation when compared to non-coated hydroxyapatite surfaces [41]. An additional mechanism suggesting that laminin may be a bone stimulating coating agent is the possible interaction of the arginine-glycine-aspartic acid (RGD) motif with the integrin receptors of the surrounding cells. It has been reported that when RGD-sequences are coated on implants, osseointegration $[36,42]$ seems to be enhanced, and the osteoblast adhesion appears to be upregulated through integrin-mediated mechanisms [43]. Nevertheless, the complexity of the in vivo environment makes it imperative to further investigate parameters such as the retention and the clearance of the coating before any further conclusions may be drawn regarding the suitability of laminin as a biomaterial coating agent.

\section{CONCLUSIONS}

The results of the present study demonstrate that after 2 weeks of incubation in SBF all the laminin coated titanium surfaces, including the laminin coated blasted controls, induced a higher $\mathrm{CaP}$ deposition as compared to uncoated blasted titanium discs. Among the tested surface modifications, alkali and heat treatment seemed to induce a more rapid $\mathrm{CaP}$ precipitation. Our study demonstrates that laminin may have the potential to be used as a coating agent in order to enhance the osseoinductive performance of biomaterial surfaces with the protein molecules possibly functioning as nucleation centres for apatite formation. In vivo studies are however needed in order to further investigate the possible effect of laminin as a coating agent in the osseointegration of titanium implants.

\section{ACKNOWLEDGMENTS AND DISCLOSURE STATEMENTS}

The authors thank Agneta Askendal from the department of Applied Physics in Linköping University, Sweden for her assistance on the protein coating process. This study was supported by the Swedish National Graduate School in Odontological Science. The authors also acknowledge the Swedish Research Council (K2009-52X-06533-27-3), Hjalmar Svenson Research Foundation, Sylvan Foundation, Wilhelm and Martina Lundgren Science Foundation, the Royal Society of Arts and Sciences in Göteborg and the Council for Research and Development in Södra Älvsborg, Sweden for funding the project. 


\section{REFERENCES}

1. Kim HM, Miyaji F, Kokubo T, Nakamura T. Preparation of bioactive Ti and its alloys via simple chemical surface treatment. J Biomed Mater Res. 1996 Nov;32(3):409-17. [Medline: 8897146] [doi: 10.1002/(SICI)1097-4636(199611)32:3<409::AID-JBM14>3.0.CO;2-B]

2. Ishizawa H, Fujino M, Ogino M. Mechanical and histological investigation of hydrothermally treated and untreated anodic titanium oxide films containing Ca and P. J Biomed Mater Res. 1995 Nov;29(11):1459-68. [Medline: 8582915] [doi: 10.1002/jbm.820291118]

3. Ramires PA, Romito A, Cosentino F, Milella E. The influence of titania/hydroxyapatite composite coatings on in vitro osteoblasts behaviour. Biomaterials. 2001 Jun;22(12):1467-74. [Medline: 11374445] [doi: $10.1016 /$ S0142-9612(00)00269-6]

4. Xiao SJ, Textor M, Spencer ND, Wieland M, Keller B, Sigrist H. Immobilization of the cell-adhesive peptide Arg-GlyAsp-Cys (RGDC) on titanium surfaces by covalent chemical attachment. J Mater Sci Mater Med. 1997 Dec;8(12):867-72. [Medline: 15348806] [doi: 10.1023/A:1018501804943]

5. Bhakta S, Pattanayak DK, Takadama H, Kokubo T, Miller CA, Mirsaneh M, Reaney IM, Brook I, van Noort R, Hatton PV. Prediction of osteoconductive activity of modified potassium fluorrichterite glass-ceramics by immersion in simulated body fluid. J Mater Sci Mater Med. 2010 Nov;21(11):2979-88. Epub 2010 Aug 20. [Medline: 20725768] [doi: $10.1007 / \mathrm{s} 10856-010-4145-\mathrm{y}]$

6. Will J, Hoppe A, Müller FA, Raya CT, Fernández JM, Greil P. Bioactivation of biomorphous silicon carbide bone implants. Acta Biomater. 2010 Dec;6(12):4488-94. Epub 2010 Jul 6. [Medline: 20615484] [doi: 10.1016/j.actbio.2010.06.036]

7. Yada M, Inoue Y, Akihito G, Noda I, Torikai T, Watari T, Hotokebuchi T. Apatite-forming ability of titanium compound nanotube thin films formed on a titanium metal plate in a simulated body fluid. Colloids Surf B Biointerfaces. 2010 Oct 15;80(2):116-24. Epub 2010 May 31. [Medline: 20580538] [doi: 10.1016/j.colsurfb.2010.05.032]

8. Kokubo T, Kushitani H, Sakka S, Kitsugi T, Yamamuro T. Solutions able to reproduce in vivo surface-structure changes in bioactive glass-ceramic A-W. J Biomed Mater Res. 1990 Jun;24(6):721-34. [Medline: 2361964] [doi: $10.1002 / \mathrm{jbm} .820240607$ ]

9. Peltola T, Pätsi M, Rahiala H, Kangasniemi I, Yli-Urpo A. Calcium phosphate induction by sol-gel-derived titania coatings on titanium substrates in vitro. J Biomed Mater Res. 1998 Sep 5;41(3):504-10. [Medline: 9659622] [doi: 10.1002/(SICI) 1097-4636(19980905)41:3<504::AID-JBM22>3.0.CO;2-G]

10. Takadama H, Kim HM, Kokubo T, Nakamura T. TEM-EDX study of mechanism of bonelike apatite formation on bioactive titanium metal in simulated body fluid. J Biomed Mater Res. 2001 Dec 5;57(3):441-8. [Medline: 11523039] [doi: 10.1002/1097-4636(20011205)57:3<441::AID-JBM1187>3.0.CO;2-B]

11. Barrere F, Snel MM, van Blitterswijk CA, de Groot K, Layrolle P. Nano-scale study of the nucleation and growth of calcium phosphate coating on titanium implants. Biomaterials. 2004 Jun;25(14):2901-10. [Medline: 14962569] [doi: 10.1016/j.biomaterials.2003.09.063]

12. Kokubo T, Takadama H. How useful is SBF in predicting in vivo bone bioactivity? Biomaterials. 2006 May;27(15):290715. Epub 2006 Jan 31. Review. [Medline: 16448693] [doi: 10.1016/j.biomaterials.2006.01.017]

13. Liu Y, Layrolle P, de Bruijn J, van Blitterswijk C, de Groot K. Biomimetic coprecipitation of calcium phosphate and bovine serum albumin on titanium alloy. J Biomed Mater Res. 2001 Dec 5;57(3):327-35. [Medline: 11523027] [doi: 10.1002/1097-4636(20011205)57:3<327::AID-JBM1175>3.0.CO;2-J]

14. Bauer S, Park J, von der Mark K, Schmuki P. Improved attachment of mesenchymal stem cells on superhydrophobic TiO2 nanotubes. Acta Biomater. 2008 Sep;4(5):1576-82. Epub 2008 Apr 25. [Medline: 18485845] [doi: 10.1016/j.actbio.2008.04.004]

15. El-Ghannam A, Starr L, Jones J. Laminin-5 coating enhances epithelial cell attachment, spreading, and hemidesmosome assembly on Ti-6A1-4V implant material in vitro. J Biomed Mater Res. 1998 Jul;41(1):30-40. [Medline: 9641621] [doi: 10.1002/(SICI) 1097-4636(199807)41:1<30::AID-JBM4>3.0.CO;2-R]

16. Werner S, Huck O, Frisch B, Vautier D, Elkaim R, Voegel JC, Brunel G, Tenenbaum H. The effect of microstructured surfaces and laminin-derived peptide coatings on soft tissue interactions with titanium dental implants. Biomaterials. 2009 Apr;30(12):2291-301. Epub 2009 Jan 24. [Medline: 19168216] [doi: 10.1016/j.biomaterials.2009.01.004]

17. Colognato H, Yurchenco PD. Form and function: the laminin family of heterotrimers. Dev Dyn. 2000 Jun;218(2):213-34. Review. [Medline: 10842354] [doi: 10.1002/(SICI)1097-0177(200006)218:2<213::AID-DVDY1>3.0.CO;2-R]

18. Hynes RO. Cell adhesion: old and new questions. Trends Cell Biol. 1999 Dec;9(12):M33-7. Review. [Medline: 10611678] [doi: 10.1016/S0962-8924(99)01667-0]

19. Roche P, Goldberg HA, Delmas PD, Malaval L. Selective attachment of osteoprogenitors to laminin. Bone. 1999 Apr;24(4):329-36. [Medline: 10221545] [doi: 10.1016/S8756-3282(98)00194-X] 
20. Roche P, Rousselle P, Lissitzky JC, Delmas PD, Malaval L. Isoform-specific attachment of osteoprogenitors to laminins: mapping to the short arms of laminin-1. Exp Cell Res. 1999 Aug 1;250(2):465-74. [Medline: 10413600] [doi: 10.1006/excr.1999.4518]

21. Vukicevic S, Luyten FP, Kleinman HK, Reddi AH. Differentiation of canalicular cell processes in bone cells by basement membrane matrix components: regulation by discrete domains of laminin. Cell. 1990 Oct 19;63(2):437-45. [Medline: 2208292] [doi: 10.1016/0092-8674(90)90176-F]

22. Kim HM, Miyaji F, Kokubo T, Nakamura T. Effect of heat treatment on apatite-forming ability of Ti metal induced by alkali treatment. J Mater Sci Mater Med. 1997 Jun;8(6):341-7. [Medline: 15348733] [doi: 10.1023/A:1018524731409]

23. Kim HM, Miyaji F, Kokubo T, Nishiguchi S, Nakamura T. Graded surface structure of bioactive titanium prepared by chemical treatment. J Biomed Mater Res. 1999 May;45(2):100-7. [Medline: 10397963] [doi: 10.1002/(SICI)1097-4636(199905)45:2<100::AID-JBM4>3.0.CO;2-0]

24. Sul YT, Johansson C, Byon E, Albrektsson T. The bone response of oxidized bioactive and non-bioactive titanium implants. Biomaterials. 2005 Nov;26(33):6720-30. [Medline: 15975649] [doi: 10.1016/j.biomaterials.2005.04.058]

25. Sul YT, Johansson CB, Jeong Y, Albrektsson T. The electrochemical oxide growth behaviour on titanium in acid and alkaline electrolytes. Med Eng Phys. 2001 Jun;23(5):329-46. [Medline: 11435147] [doi: 10.1016/S1350-4533(01)00050-9]

26. Sul YT, Johansson CB, Albrektsson T. Oxidized titanium screws coated with calcium ions and their performance in rabbit bone. Int J Oral Maxillofac Implants. 2002 Sep-Oct;17(5):625-34. [Medline: 12381062]

27. Sul YT, Johansson CB, Petronis S, Krozer A, Jeong Y, Wennerberg A, Albrektsson T. Characteristics of the surface oxides on turned and electrochemically oxidized pure titanium implants up to dielectric breakdown: the oxide thickness, micropore configurations, surface roughness, crystal structure and chemical composition. Biomaterials. 2002 Jan;23(2):491-501. [Medline: 11761170] [doi: 10.1016/S0142-9612(01)00131-4]

28. Kjellin P, Andersson M. Synthetic nano-sized crystalline calcium phosphate and method of production patent. 2008 Nov. URL: http://www.faqs.org/patents/app/20080220233

29. Linderbäck P, Harmankaya N, Askendal A, Areva S, Lausmaa J, Tengvall P. The effect of heat- or ultra violet ozonetreatment of titanium on complement deposition from human blood plasma. Biomaterials. 2010 Jun;31(18):4795-801. Epub 2010 Apr 3. [Medline: 20363497] [doi: 10.1016/j.biomaterials.2010.02.060]

30. McCrackin FL. A Fortran program for analysis of ellipsometer measurements.. Washington DC; 1969. p. 479.

31. Oyane A, Kim HM, Furuya T, Kokubo T, Miyazaki T, Nakamura T. Preparation and assessment of revised simulated body fluids. J Biomed Mater Res A. 2003 May 1;65(2):188-95. [Medline: 12734811] [doi: 10.1002/jbm.a.10482]

32. Wennerberg A, Albrektsson T. Suggested guidelines for the topographic evaluation of implant surfaces. Int J Oral Maxillofac Implants. 2000 May-Jun;15(3):331-44. [Medline: 10874798]

33. Wildemann B, Sander A, Schwabe P, Lucke M, Stöckle U, Raschke M, Haas NP, Schmidmaier G. Short term in vivo biocompatibility testing of biodegradable poly(D,L-lactide)--growth factor coating for orthopaedic implants. Biomaterials. 2005 Jun;26(18):4035-40. [Medline: 15626449] [doi: 10.1016/j.biomaterials.2004.10.004]

34. Jimbo R, Sawase T, Shibata Y, Hirata K, Hishikawa Y, Tanaka Y, Bessho K, Ikeda T, Atsuta M. Enhanced osseointegration by the chemotactic activity of plasma fibronectin for cellular fibronectin positive cells. Biomaterials. 2007 Aug;28(24):346977. Epub 2007 May 3. [Medline: 17512051] [doi: 10.1016/j.biomaterials.2007.04.029]

35. Ishibe T, Goto T, Kodama T, Miyazaki T, Kobayashi S, Takahashi T. Bone formation on apatite-coated titanium with incorporated BMP-2/heparin in vivo. Oral Surg Oral Med Oral Pathol Oral Radiol Endod. 2009 Dec;108(6):867-75. Epub 2009 Sep 26. [Medline: 19782617] [doi: 10.1016/j.tripleo.2009.06.039]

36. Valderrama P, Jung RE, Thoma DS, Jones AA, Cochran DL. Evaluation of parathyroid hormone bound to a synthetic matrix for guided bone regeneration around dental implants: a histomorphometric study in dogs. J Periodontol. 2010 May;81(5):737-47. [Medline: 20429653] [doi: 10.1902/jop.2010.090562]

37. Arvidsson A, Franke-Stenport V, Andersson M, Kjellin P, Sul YT, Wennerberg A. Formation of calcium phosphates on titanium implants with four different bioactive surface preparations. An in vitro study. J Mater Sci Mater Med. 2007 Oct;18(10):1945-54. Epub 2007 Jun 7. [Medline: 17554602] [doi: 10.1007/s10856-007-3097-3]

38. Bougas K, Stenport VF, Currie F, Wennerberg A. In vitro Evaluation of Calcium Phosphate Precipitation on Possibly Bioactive Titanium Surfaces in the Presence of Laminin. J Oral Maxillofac Res 2011;2(3):e3. [URL: http://www.ejomr.org/JOMR/archives/2011/3/e3/v2n3e3ht.htm] [doi: 10.5037/jomr.2011.230339]

39. Rodríguez Hernández JC, Salmerón Sánchez M, Soria JM, Gómez Ribelles JL, Monleón Pradas M. Substrate chemistry-dependent conformations of single laminin molecules on polymer surfaces are revealed by the phase signal of atomic force microscopy. Biophys J. 2007 Jul 1;93(1):202-7. Epub 2007 Apr 6. [Medline: 17416620] [doi: 10.1529/biophysj.106.102491] [ [FREE Full Text]

40. Lee HL, Bae OY, Baek KH, Kwon A, Hwang HR, Qadir AS, Park HJ, Woo KM, Ryoo HM, Baek JH. High extracellular calcium-induced NFATc3 regulates the expression of receptor activator of NF- $\kappa$ B ligand in osteoblasts. Bone. 2011 Aug;49(2):242-9. Epub 2011 Apr 14. [Medline: 21514407] [doi: 10.1016/j.bone.2011.04.006] 
41. Mavropoulos E, Costa AM, Costa LT, Achete CA, Mello A, Granjeiro JM, Rossi AM. Adsorption and bioactivity studies of albumin onto hydroxyapatite surface. Colloids Surf B Biointerfaces. 2011 Mar;83(1):1-9. Epub 2010 Oct 19. [Medline: 21109408] [doi: 10.1016/j.colsurfb.2010.10.025]

42. Kroese-Deutman HC, van den Dolder J, Spauwen PH, Jansen JA. Influence of RGD-loaded titanium implants on bone formation in vivo. Tissue Eng. 2005 Nov-Dec;11(11-12):1867-75. [Medline: 16411833] [doi: 10.1089/ten.2005.11.1867]

43. Kilpadi KL, Chang PL, Bellis SL. Hydroxylapatite binds more serum proteins, purified integrins, and osteoblast precursor cells than titanium or steel. J Biomed Mater Res. 2001 Nov;57(2):258-67. [Medline: 11484189] [doi: 10.1002/1097-4636(200111)57:2<258::AID-JBM1166>3.0.CO;2-R]

\section{To cite this article:}

Bougas K, Stenport VF, Tengvall P, Currie F, Wennerberg A. Laminin Coating Promotes Calcium Phosphate Precipitation on Titanium Discs in vitro.

J Oral Maxillofac Res 2011;2(4):e5

URL: http://www.ejomr.org/JOMR/archives/2011/4/e5/v2n4e5ht.pdf

doi: $10.5037 /$ jomr.2011.2405

Copyright (C) Bougas K, Stenport VF, Tengvall P, Currie F, Wennerberg A. Accepted for publication in the JOURNAL OF ORAL \& MAXILLOFACIAL RESEARCH (http://www.ejomr.org), 16 September 2011.

This is an open-access article, first published in the JOURNAL OF ORAL \& MAXILLOFACIAL RESEARCH, distributed under the terms of the Creative Commons Attribution-Noncommercial-No Derivative Works 3.0 Unported License, which permits unrestricted non-commercial use, distribution, and reproduction in any medium, provided the original work and is properly cited. The copyright, license information and link to the original publication on (http://www.ejomr.org) must be included. 